\title{
ОБЩИЙ ПОДХОД к ПОНЯтИю КОРРУПцИИ
}

\section{AN OVERVIEW OF THE CONCEPT OF CORRUPTION}

O. Aslanov

Summary. In addition to giving different definitions of corruption, the article is also about explain its essence. In addition, the article also clarifies the essence and content of the views expressed by individual authors in the legal literature on corruption crimes.

Keywords: corruption, corruption crimes, official, abuse of office, bribery, plunder of public property.

\author{
Асланов Орхан Руфат оглы \\ Докторант, Бакинский Государственный \\ университет \\ aslanov.orxan@gmail.com
}

Аннотация. Помимо различных определений коррупции, в статье также делается попытка разъяснения ее сути. Кроме того, в статье, ссылаясь на мысли, высказываемые со стороны отдельных авторов в юридической литературе, связанной с коррупционными преступлениями, вносится ясность в суть и содержание этих мыслей.

Ключевые слова: коррупция, коррупционные преступления, должностное лицо злоупотребление служебными полномочиями, взятка, разграбление государственного имущества.

нег, ценностей, другого имущества или оказание услуг имущественного характера для себя или для третьих лиц и т.д., незаконное использование служебного положения с целью получения выгоды в виде прочих имущественных прав или незаконной передачи таких выгод этому лицу другими физическими лицами, а также совершения таких действий от имени или в интересах юридического лица.

На основании Конвенции ООН от 2003-го года “О борьбе с коррупцией", в понятие коррупции были включены действия, совершаемые в корыстных целях: подкуп взяткой должностных лиц иностранных государств и служащих международных межгосударственных организаций; разграбление, присвоение или постороннее использование в других целях в государственного имущества со стороны должностных лиц; торговля авторитетом и др.

Коррупция подразумевает не только взятку в виде денег или подарков. Взяточничество - одна из различных форм коррупции, а коррупция - это многогранное понятие. Согласно исследованию, проведенному в 1995 году национальными отделениями международной организации «Transparency International», из форм коррупции, наблюдаемых в государственных, муниципальных и неправительственных организациях, были выделены особое гостеприимство, проявляемое предпринимателями по отношению к чиновникам, признаки особого уважения, проявляемые предпринимателями к членам семей чиновников, покровительство чиновников над определенными государственными контактами, меры в отношении их частых поездок за границу, использование власти политическими партиями и финансовая поддержка политических кампа- 
ний; требование взятки от предпринимателей со стороны налоговых и таможенных служащих, угрожающих повышением налогов и таможенных тарифов, а также взятка чиновникам за создание льготных условий для предпринимателей и так далее.

Следует отметить, что основными сферами участия государства и коррупции в странах с переходной экономикой являются:

- приватизация государственного имущества;

- исполнение бюджета и распределение бюджетных средств;

- предоставление исключительных прав;

- незаконный лоббизм в органах законодательства;

- слияние экономической преступности с правоохранительными органами и др.

Также следует отметить, что нет единого стандарта для понятия коррупции как социального явления, в частности, связанным с ее правовым объемом и содержанием, и нет единого подхода к этому вопросу. Однако можно найти общие критерии, объединяющие их в данных понятиях коррупции. Коррупция возникает, когда должностное лицо использует свои законные полномочия или положение в целях получения дохода или обогащения, а также в обмен на определенные материальные или другие выгоды или привилегии в обмен на отказ этого должностного лица сделать это или отказаться от этого.

Прежде всего, следует отметить, что коррупция это нарушение нормальных процессов должностными лицами и приравненными к ним лицами, злоупотребление ими служебным положением в личных целях, предварительный сговор и принятие незаконных решений, а также преступная деятельность, связанная с получением чужих денег, ценных бумаг, имущества, имущественных благ и привилегий или их отчуждением другим заинтересованным лицам.

Характеристика коррупционных преступлений показывает, что их последствия очень тяжелы. Поэтому коррупцию следует расценивать как проявление угрозы государству и его национальной безопасности [10, c. 11].

В целом понятие коррупции по-разному трактуется в международно-правовых документах. Межведомственная комиссия Совета Европы по коррупции дала коррупции такое понятие, как деятельность, проводимая в жизнь для собственной выгоды или выгоды другого лица, использующего свое служебное положение, определенного статусом этой должности (государственный чиновник, индивидуальный сотрудник, неза- висимый агент и др.) по причине взяточничества или другого действия должностного лица в государственном или частном секторе. Комиссия показала, что субъект коррупции состоит только из должностных лиц.

Конвенция Организации Объединенных Наций «Против транснациональной организованной преступности», принятая 12-15 декабря 2000-го года, понятие коррупции - это деяние, совершаемое должностным лицом лично или через посредника в обмен на любое действие или бездействие при исполнении им своих официальных обязанностей для другого физического или юридического лица, обещание, предложение или преподнесение ему любой незаконной собственности, а также требование или принятие их этим должностным лицом посредством угроз.

Необходимо также отметить, что в юридической литературе коррупции не дано одностороннего, единого понятия. Например, В.А. Шабалин определял политическую коррупцию как нелегитимное использование правящей политической элитой с целью укрепления своей власти государственных ресурсов [14, с. 146].

А В.Г. Мамедов писал, что, как правило, коррупция - это действие, совершаемое государственными чиновниками. Коррупция присутствует том случае, когда государственные чиновники управляют не принадлежащими им средствами по своему желанию. К этим средствами могут быть отнесены бюджетные средства, средства, относящиеся к государственной и муниципальной собственности, государственные заказы, льготы, гранты, ценные бумаги, государственные фонды и др. [11, с. 28-29].

Профессор Г.К. Мишин в своем труде «Коррупция понятие, значение, меры ограничения» сказал о коррупции, что коррупция - как фактор, ослабляющий государство в его социологических функциях (миссиях), является еще большим преступлением. Отсюда можно прийти к такому выводу, что спад в современном мире государственности посредством коррупции со стороны организованных преступных группировок (как национальных, так и транснациональных группировок), является глобальной проблемой, появившейся в последних десятилетиях XX века [13, с. 18].

Р.К. Мамедов дал коррупции такое понятие, как социально опасное проявление и как деятельность, оказывающая разрушительное воздействие на государственную политику и процесс управления государством путем соблазна государственных чиновников деньгами, имуществом или прочими веществами неимущественного характера, а также оказывающее разрушающее действие на политические и экономические 
основы государства путем шантажа или провокаций $[12$, c. 19].

В целом, отметим, что уголовное законодательство нашей страны получившей независимость, в настоящее время дала уже понятие легальной коррупции. Так, в Законе Азербайджанской Республики от 13 января 2004-го года «О борьбе с коррупцией» коррупции дано такое понятие, что коррупция - это незаконное приобретение материальных и прочих ценностей, льгот или привилегий путем использования должностными лицами своего статуса, статуса представляемого им органа, должностными полномочиями или использования возможностей, вытекающих из должностных полномочий или этих статусов и полномочий, а также подкуп этих должностных лиц путем незаконного предложения или обещания или передачи должностным лицам со стороны физических и юридических лиц указанных материальных и прочих ценностей, льгот или привилегий [15].

Другой привлекающий внимание момент заключается в том, что в данном случае коррупция выходит за рамки понятия взяточничества, и эти два понятия, независимо от того, насколько они близки друг к другу, различаются по своим характеристикам. С этой точки зрения отношение коррупции к взяточничеству можно охарактеризовать как отношение общего к частному. Так, понятие коррупции включает в себя как взяточничество (предоставление ему подарка, чтобы отвлечь его от его служебного положения), поощрение (покровительство на основе личных отношений), так и незаконное присвоение государственных средств в личных целях [7, с. 13].

Из вышесказанного ясно, что понятие коррупции определяется по-разному и оно оценивается не одинаково. Именно поэтому невозможно получить положительные результаты в борьбе с коррупцией. Даже часть авторов, указывая бессмысленность борьбы с этим преступлением, отмечают, что коррупция - это преступление без жертв и нераскрываемое преступление.

А из современных авторов В.Г. Мамедов предлагает такую подачу понятия коррупции:“Коррупция - это нарушение обычных процессов путем заранее принятой договоренности для принятия решений о незаконном приобретении денег, ценных бумаг, имущества, прибыли и выгод другого лица путем злоупотребления долж- ностей и фальсификации государственных служащих и приравненных к ним лиц для личной выгоды; такое отчуждение или захват другими заинтересованными сторонами, которое наносит серьезный вред охраняемым законом интересам государства, общественных организаций, муниципальных образований и граждан $[10$, с. 37].

В то же время, о коррупции существуют также различные мысли. В общем, взяточничество, незаконное присвоение государственной собственности, кража и незаконное присвоение государственной или частной собственности путем мошенничества, получение собственности и выгод имущественного характера путем злоупотребления властью, уклонение от уплаты налогов, взяточничество путем подстрекательства, распространение коммерческой тайны и т.д. в правовых системах стран, где коррупционные правонарушения не регулируются по конкретным правовым нормам, связывают с коррупцией. По отдельности ни одно из них не создает состав коррупционного преступления, и каждое из них в отдельности регулируется конкретными правовыми нормами. Отсутствие единого понимания коррупции, в свою очередь, приводит к замешательству ученых, сотрудников правоохранительных органов и общества, что создает представление о невозможности борьбы с коррупцией и диктует неэффективность борьбы с ней [10, с. 37-38].

Следует отметить, что хотя существует множество определений коррупции, ни одно из них не отличается четкостью и юридической точностью. Это естественно. Потому что понятие коррупции является больше понятием социальным и криминологическим, чем правовым. Поэтому было бы более верным подходить к нему не как к составу конкретного преступления, а как к своду однотипных действий.

Сегодня отношение к самому понятию коррупции различное, и коррупция является предметом изучения экономических, социологических, политических и юридических исследований. В то же время, коррупция обсуждается и на бытовом уровне. Поэтому дать коррупции универсальное определение не так легко, и это считается являющейся одним из факторов, немного затрудняющих построение работы по предотвращению коррупции.

\section{ЛИТЕРАТУРА}

1. Агаев И.Б. Уголовное право Азербайджанской Республики. Общая и Особенная части: Учебник / И.Б. Агаев, В.П. Ревин; предисл. В.П. Ревина. - М.: Юрист, - 2009. - 684 с.

2. Агаев И.Б. Уголовное право. Особенная часть: Учебник (на азербайджанском языке). — Баку: NURLAR, — 2018. — 488 c.

3. Гасанов Э.Г. Коррупция и правовые основы борьбы с ней (на азербайджанском языке) // — Баку: Qanunçuluq, — 2006. № 11. 
4. Гулиев Р.И., Иманов М.Н. Уголовное право. Особенная часть: Учебник (на Азербайджанском языком). — Баку: Qanun, — 2004. — 816 c.

5. Джавадов Ф., Абдуллаев Я. Исторические корни коррупции и общественной опасности (на азербайджанском языке)// — Баку: Актуальные вопросы судебной медицины, криминалистики и криминологии (сборник научных трудов), - 2013. № 59, - c. 6-26.

6. Зотова Г. Противодействие коррупции за рубежом // Преступление и наказание, — 2011. № 4, — c. $20-27$.

7. Исаев 0. Некоторые заметки о понятии коррупции ((на азербайджанском языке)// Коррупция: понятие, основные черты и исследование.- Баку: Hüquq $\nabla d \nabla b i y y a t ı,-2010 .-207$ c.

8. Комментарий к Уголовному кодексу Азербайджанской Республики / Под редакцией д.ю.н, проф. Ф.Ю. Самандарова. Доработанная перепечатка. Часть II. Толкование статей 190-353 УК АР (на азербайджанском языке). — Баку: Hüquq Yayın Evi, — 2018. — 800 c.

9. Максимов С.В. Коррупция. Закон. Ответственность. - М.: ЮрИнфоР,-2000. - 143 с.

10. Мамедов В.Г. Вопросы противодействия коррупционным преступлениям (на азербайджанском языке). — Баку: Adiloğlu, — 2006. — $186 c$.

11. Мамедов В.Г. Вопросы противодействия коррупционным преступлениям (на азербайджанском языке): / дисс. к.ю.н. / — Баку, 2005.— 181 с.

12. Мамедов Р.К. 0 некоторых вопросах борьбы с коррупцией с точки зрения требований нового законодательства (на азербайджанском языке) // Материалы научного семинара «Коррупция и борьба с ней», - Баку: Qanun, - 2001. — c. 18-21.

13. Мишин Г.К. Коррупция: понятие, сущность, меры ограничения.-М.: Юрист, - 1991. - 158 с.

14. Шабалин В.А. Политика и преступность // Государство и право, - 1994. № 4, — c. 145-151.

15. http://www.e-qanun.az/framework/5809 — Закон Азербайджанской Республики от 13 января 2004-го года «0 борьбе с коррупцией»

16. http://www.e-qanun.az/framework/46947 — Уголовный Кодекс Азербайджанской Республики от 30 декабря 1999-го года.

(c) Асланов Орхан Руфат оглы ( aslanov.orxan@gmail.com ).

Журнал «Современная наука: актуальные проблемы теории и практики»

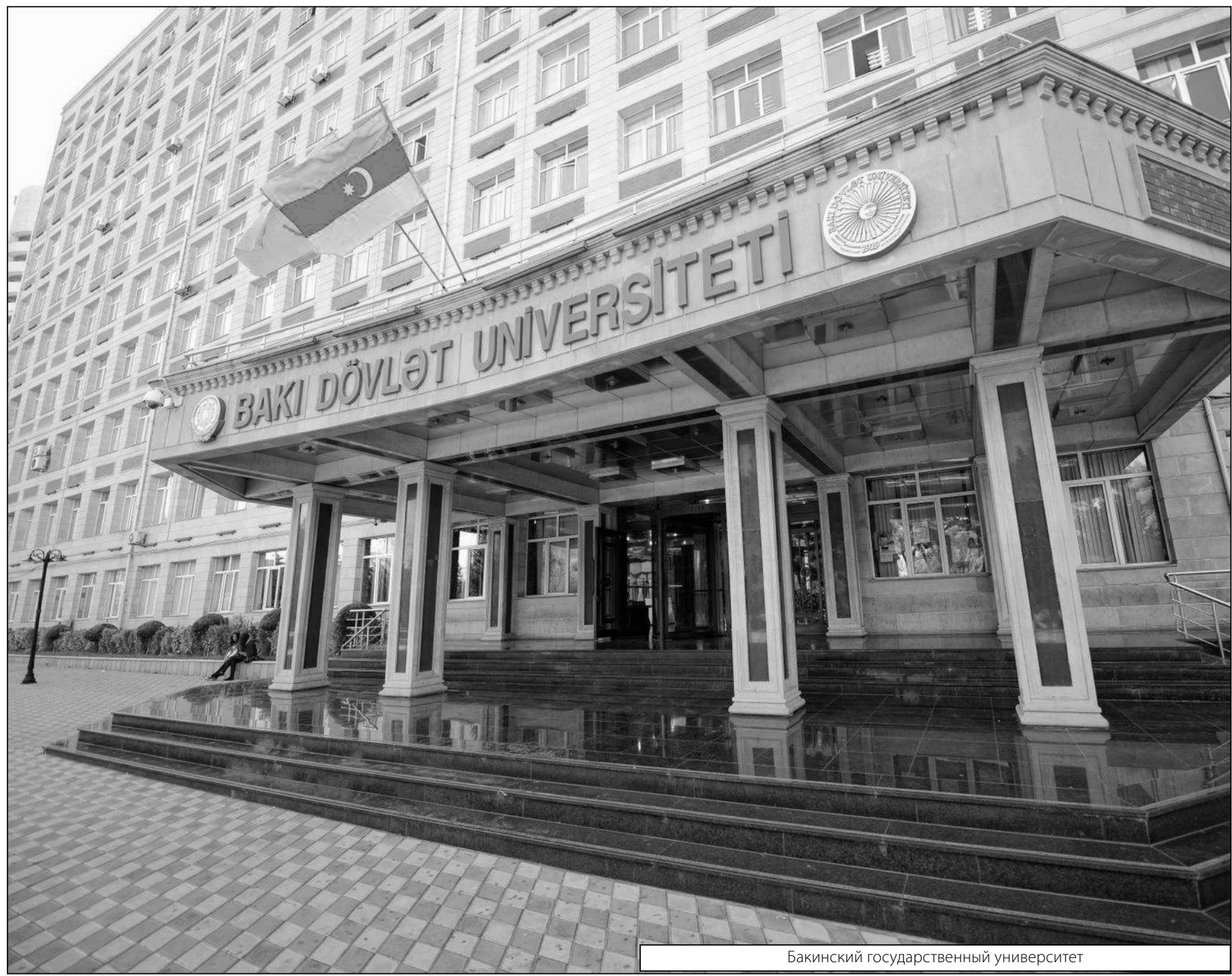

